\title{
ANCAMAN TEORI-TEORI YANG MENYIMPANG TENTANG PENEBUSAN DALAM KEHIDUPAN ORANG KRISTEN
}

\author{
Lie Ja Hwe \\ Sekolah Tinggi Teologi Efata, Salatiga \\ santosayulia@yahoo.com
}

\begin{tabular}{|l|l|l|}
\hline Diterima : 15 Desember 2021 & Direvisi : 19 Desember 2021 & Disetujui : 20 Desember 2021 \\
\hline
\end{tabular}

\section{ABSTRACT}

The redemption and work of the Lord Jesus Christ is an important event in Christianity. God in the form of Jesus Christ provided salvation for fallen mankind. God provided salvation through the sacrifice of Jesus Christ on the cross so that He became the Redeemer of mankind. This theory is the correct theory of redemption. There cannot be more than two theories about redemption. However, since the early church century there have been distorted theories about redemption. These theories are subjective and can be a threat to Christians, thus affecting their faith and their relationship with God. The purpose of this paper is to explain Christ's atoning work, an analysis of distorted theories of atonement, and the attitude of Christians to aberrant teachings about redemption. Through a literature study, an understanding of Christ's work of redemption will be presented so that Christians will have the right attitude, be aware of deviant teachings about redemption so that they will reject teachings that are not in accordance with God's Word. Key words: deviant theory, redemption, christian

\begin{abstract}
ABSTRAK
Penebusan dan karya Tuhan Yesus Kristus merupakan peristiwa penting dalam kekristenan. Allah dalam wujud Yesus Kristus menyediakan keselamatan bagi umat manusia yang telah jatuh dalam dosa. Allah menyediakan keselamatan melalui pengorbanan Yesus Kristus di kayu salib sehingga Dia menjadi Penebus umat manusia. Teori ini adalah teori yang benar tentang penebusan. Tidak mungkin lebih dari dua teori tentang penebusan. Namun, sejak gereja abad mul-mula telah muncul teori-teori yang menyimpang tentang penebusan. Teori-teori ini bersifat subjektif dan dapat menjadi ancaman bagi orang Kristen sehingga mempengaruhi iman dan relasi orang Kristen dengan Tuhan. Tujuan tulisan ini adalah untuk menjelaskan karya penebusan Kristus, analisa terhadap teori-teori yang menyimpang tentang penebusan, dan sikap orang Kristen menghadapi ajaran yang menyimpang tentang penebusan. Melalui studi pustaka akan dikemukakan pemahaman tentang karya penebusan Kristus sehingga orang Kristen akan memiliki sikap yang benar, mewaspadai ajaran-ajaran yang menyimpang tentang penebusan sehingga akan menolak ajaran yang tidak sesuai dengan Firman Allah.

Kata-kata kunci: teori menyimpang, penebusan, orang Kristen
\end{abstract}




\section{PENDAHULUAN}

Karya Allah di dalam penebusan Kristus menjadi dasar orang percaya mengalami pendamaian dengan Allah dan memperoleh hidup yang kekal di dalam Kristus. Manusia akan tetap berada dalam perbudakan dosa dan terpisah dari Allah bila tanpa karya penebusan Kristus. Keselamatan kekal melalui penebusan Kristus merupakan anugerah yang diberikan Allah kepada manusia.. ${ }^{1} \mathrm{Hal}$ ini merupakan wujud nyata kasih Allah yang kekal kepada manusia. Allah mengutus anak-Nya yang tunggal, Yesus Kristus sebagai penebus bagi manusia berdosa. Penebusan Kristus merupakan tindakan kasih yang sangat melimpah kepada manusia. "Karena begitu besar kasih Allah akan dunia ini, sehingga la telah mengaruniakan Anak-Nya yang tunggal, supaya setiap orang yang percaya kepada-Nya tidak binasa, melainkan beroleh hidup yang kekal. Sebab Allah mengutus Anak-Nya ke dalam dunia bukan untuk menghakimi dunia, melainkan untuk menyelamatkannya oleh Dia (Yohanes 3:16-17). Manusia akan tetap dalam penghukuman dosa bila Allah tidak berinisiatif dalam kasih-Nya untuk menyelamatkan manusia (Yohanes 3:18).

Penebusan dosa yang dikerjakan Yesus Kristus adalah anugerah Allah untuk keselamatan manusia. Hanya Yesus Kristus yang dapat menebus manusia dari perbudakan dosa melalui kematian-Nya dengan harga yang sangat mahal, yaitu mengorbankan diri-Nya sendiri. ${ }^{2}$ Paulus menyatakan "Sebab kamu tahu bahwa kamu telah ditebus...dengan darah yang mahal, yaitu darah Kristus yang sama seperti darah anak domba yang tak bernoda dan bercacat" (1 Petrus 1:18-19). Manusia berdosa di bawah tawanan iblis, maka penebusan dimaksudkan untuk membayarnya. Allah menebus dosa orang percaya dari kekuasaan dosa bukan dengan harta, mealinkan dengan darah yang mahal dari Anak-Nya sendiri (Roma 6:6). Orang percaya hidup bagi Allah dalam Kristus "Demikianlah hendaknya kamu memandangnya: bahwa kamu telah mati bagi dosa, tetapi kamu hidup bagi Allah dalam Kristus" (Roma 8:1). Setelah menerima Yesus Kristus, orang percaya telah ditebus dan dibebaskan dari kekuasaan iblis dan dosa. Dalam kehidupan

\footnotetext{
${ }^{1}$ Musa S. Tarigan. “Implikasi Penebusan Kristus Dalam Pendidikan Kristen (The Implication Of Christ's
} Redemption On Christian Education)", Jurnal Polyglot. Volume 15, No. 2, Juli 2019, 208.

${ }^{2}$ Surja Kusuma. Kompas Iman (Yogyakarta: Rangkang Education, 2016), 172. 


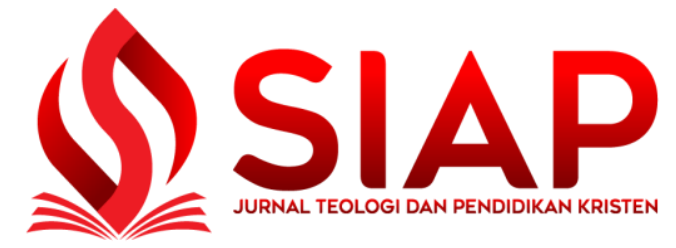

Vol. 10, No. 2 (Desember 2021)

Available Online at :

https://ejournal.sttjki.ac.id/index.php/siap/index

ISSN : 2302-5336X (Cetak) 2808-0459 (Online)

iman Kristen, penebusan Kristus merupakan hal yang sangat penting Kematian Kristus adalah pernyataan tertinggi tentang kasih Allah. Berkaitan dengan hal ini, Paulus menegaskan secara berulang-ulang dalam surat-suratnya bahwa kasih Allah diperoleh orang percaya melalui penebusan Kristus yang dikerjakan-Nya melalui kematian Kristus di kayu salib (2 Korintus 5:19). Dalam Roma 5:8 menyatakan “Akan tetapi Allah menunjukkan kasih-Nya kepada kita, oleh karena Kristus telah mati untuk kita, ketika kita masih berdosa". Kasih Allah kepada manusia menjadikan manusia dapat dipersatukan kembali dalam persekutuan kasih ilahi di dalam diri Allah Tritunggal. Wujud kasih manusia kepada kasih Allah adalah menerima dan percaya kepada Tuhan Yesus Kristus, Anak Tunggal-Nya. Tanggapan dari manusia menyebabkan persekutuan kasih dapat terwujud efektif

Dalam Galatia 3:13 menyatakan bahwa Kristus telah menebus kita dari hukum Taurat dengan jalan menjadi kutuk karena kita. Kutuk hokum Taurat adalah hukuman mati. Tanpa pelepasan dari kutuk ini, tidak mungkin ada keselamatan. Tuhan Yesus membayar kita dan harga pembayaran itu adalah diri-Nya sendiri harus dijadikan kutuk. Kutuk itulah yang la tanggung dan kutuk itulah yang la lepaskan, Inilah harga yang telah dibayar Kristus demi penebusan dan kebebasan kita dari belenggu iblis, dosa, dan maut. Dengan demikian, penebusan Kristus adalah kelepasan yang final dan lengkap. Darah Kristus sebagai bayaran pengganti dan sebagai harga pembayaran atas kelepasan manusia berdosa dari kutuk.

\section{METODE}

Penelitian ini adalah penelitian kualitatif deskriptif yang berlandaskan pada studi pustaka. Penulis melakukan studi pustaka terhadap beberapa sumber yang terkait dengan teori-teori yang menyimpang tentang penebusan. Sumber utama dari analisis data adalah dari berbagai macam buku dan jurnal hasil penelitian yang relevan yang berkaitan dengan teori-teori yang menyimpang tentang penebusan dan dasar Alkitab mengenai Yesus Kristus Penebus umat manusia. 


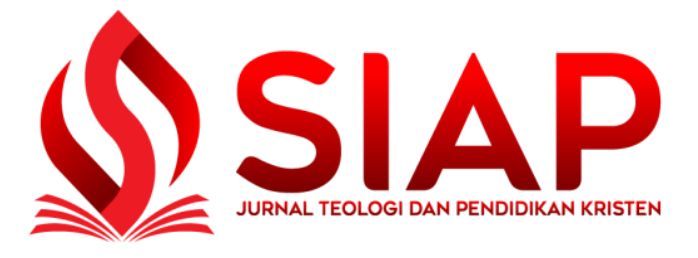

Vol. 10, No. 2 (Desember 2021)

Available Online at :

https://ejournal.sttjki.ac.id/index.php/siap/index

ISSN : 2302-5336X (Cetak) 2808-0459 (Online)

\section{TEMUAN DAN PEMBAHASAN}

\section{Karya Penebusan Kristus}

Tindakan penebusan adalah tindakan paling mulia yang Allah perbuat. dalam hubungan Allah dengan manusia. Perbuatan ini atas dasar kasih. Allah Bapa memiliki inisiatif untuk mengutus Tuhan Yesus Krsitus ke dalam dunia agar semua umat manusia tidak binasa. Hanya Yesus Kristuslah yang dapat membebasakan umat manusia dari dosa karena Dailah yang akan mendamaikan umat manusia dengan Allah. Oleh karena it, Allah di dalam Yesus Kristus menyediakan jalan keselamatan bagi manusia. Allah Bapa menyediakan keselamatan melalui pengorbanan Yesus Krsitus di kayu salib. Allah memakai cara ini untuk menyatakan kasih-Nya kepada seluruh umat manusia. ${ }^{3}$ Tanpa campur tangan manusia, Allah bertindak dengan cara-Nya sendiri. Tuhan Yesus Kristus menjadi Penebus umat manusia. Allah mengorbankan anak-Nya yang tunggal untuk menebus dosa manusia. "Kristus tidak berdosa, tetapi Allah membaut Dia menanggung dosa kita, supaya kita berbalik kembali (berdamai) dengan Allah karena bersatu dengan Kristus (2 Koriuntus 5:21).

Tuhan Yesus menyadari dengan sepenuhnya bahwa Dia harus mati membebaskan manusia dari dosa dan kematian kekal, serta menyediakan kehidupan kekal bagi mereka. Yesus mengorbankan diri-Nya untuk mempersatukan manusia berdosa dengan Allah Bapa dan sesama manusia. Manusia sangat membutuhkan pertolongan Ilahi. Firman Allah menyatakan bahwa hanya kematian Kristus yang dapat memulihkan hubungan antara sesama manusia dan hubungan manusia dan Allah. Kristuslah yang telah melepaskan manusia dari dosa oleh darah-Nya. Penebusan yang dilakukan Yesus Kristus hanya dapat dilakukan oleh Allah saja. Keselamatan bukan hasil perbuatan manusia. Dasar keselamatan adalah pengorbanan Yesus Krsitus karena semua manusia sudah berbuat dosa tidak terkecuali. Untuk itulah, Allah menangani persoalan dosa manusia di dalam dan melalui Yesus Kristus. Manusia menerima pembenaran yang tidak mungkin didapatkan dari hasil usahanya sendiri melalui iman kepada Kristus.

\footnotetext{
${ }^{3}$ C. B. Hogue. Keselamatan: Kebutuhan Manusia Paling Utama (Bandung: Lembaga Literatur Baptis, 1992),
} 50. 


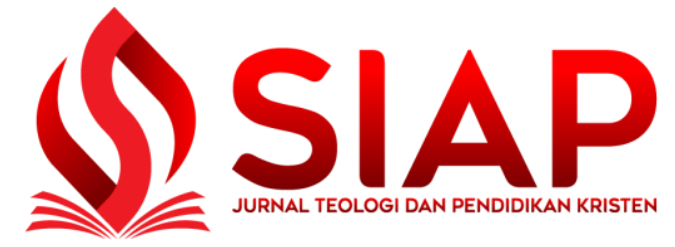

Vol. 10, No. 2 (Desember 2021)

Available Online at :

https:// ejournal.sttjki.ac.id/index.php/siap/index

ISSN : 2302-5336X (Cetak) 2808-0459 (Online)

Pendamaian sering kali berkaitan denga penggenapan penebusan yang bersumber di dalam kedaulatan dan kebebasan kasih Allah, seperti dinyatakan dalam Yohanes 3:16 "Karena begitu besar kasih Allah akan dunia ini, sehingga la telah mengaruniakan Anak-Nya yang tunggal, supaya setiap orang yang percaya kepada-Nya tidak binasa, melainkan beroleh hidup yang kekal". Kasih Allah yang menjadi sumber pendamaian adalah kasih yang berdaulat, kasih yang sejak semula memilih dan menentukan (predestinasi) untuk memberikan kepastian bagi pendamaian yang diadakan oleh Allah.

Bahasa pembayaran atau lebih tepat bahasa peluanasan adalah bahasa penebusan. Suatu jaminan pelepasan melalui pembayaran suatu harga tertentu disebut pelunasan. Kristus yang harus menjamin penebusan karena untuk menggenapkan pekerjaan penebusan. Oleh karena itu, y yang Yesus harus datang ke dunia. Kemudian, harga pelunasan adalah pemberian hidup-Nya dan penggantian adalah natur pelunasan. ${ }^{4}$ Pelunasan menunjukkan ada suatu penawanan atau belenggu, karena itu penebusan dimaksudkan untuk melepaskan belenggu dosa menuju kemerdekaan.

Dosa manusia terlalu besar. Tidak ada satupun orang di dunia yang dapat membayar hutang kepada Allah. Yesus Kristuslah yang paling sempurna, yang tidak terbatas, dan yang tidak berdosa. Dialah Juruselamat yang sah. Juruselamat dan Penebus hanya satu. Yesus menyatakan "Akulah jalan dan kebendarn dan hidup" (Yohanes 14:6). Yesus adalah wujud dari Tuhan Allah yang mau datang ke dunia dan rela menjadi manusia. Di dalam iman Kristen, di dalam Yesus Kristus, Allah telah menunjukkan betapa Dia sangat mengasihi manusia sehingga Allah datang sendiri ke dalam dunia yang Dia ciptakan untuk melawat umat manusia. ${ }^{5}$ Yesus Kristus datang ke dunia memakai tubuh manusia. Manusia berdosa dan tidak sempurna, karena itu manusia tidak layak menjadi Juruselamat untuk menggantikan orang berdosa. Yesus Kristus saja yang menaati Allah Bapa sehingga Dia diutus untuk menebus orang berdosa. Kristus adalah satu-satunya

\footnotetext{
4 John Murray, Penggenapan dan Penerapan Penebusan (Surabaya: Momentum, 2008), 46.

${ }^{5}$ Stephen Tong, Yesus Kristus Juruselamat Dunia (Surabaya: Momentum, 2005), 95.
} 


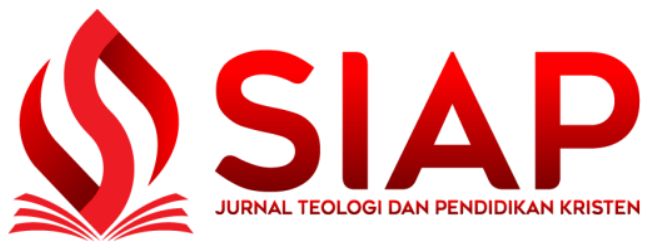

Vol. 10, No. 2 (Desember 2021)

Available Online at :

https://ejournal.sttjki.ac.id/index.php/siap/index

ISSN : 2302-5336X (Cetak) 2808-0459 (Online)

Juruselamat yang diutus oleh Alla untuk datang ke dunia. Dialah pengutusan satu-satunya dan khusus, tidak ada seorang pun yang diutus menjadi Juruselamat manusia.

Paul Enns menjelaskan istlah penebusan ditinjau secara etimologi. Pertama adalah agorazo yang berasal dari bahasa Yunani yang berarti membeli atau membayar dengan menyerahkan sesuatu sebagai harga pembayaaran yang setimpal bagi bagi sesuatu barang lainnya. Seringkali berhubungan dengan penjualan budak di pasar. Kata agorazo digunakan untuk menjelaskan orang percayayang dibeli dari pasar budak dosa dan dibebaskan dari ikatan dosa. Harga pembayaran untuk kebebasan orang percaya dari dosa adalah kematian Yesus (1 Korintus 6:20). Kedua adalah exagorazo yang mengajarkan bhahwa Yesus Kristus menebus orang percaya dari kutuk dan ikatan hokum. Orang percaya tela dibeli dari pasar budak (agorazo) dan dikeluarkan dari (ex) pasar budak sekaligus. Yesus memerdekakan orang percaya dari ikatan hukum dan dari penghukumannya (Galatia 3:13). Ketiga adalah lutro yang artinya mendapatkan kebebasan melalui pembayaran suatu harga (1 Petrus 1:18). Bahasa yang lebih spesifik adalah bahasa pelunasan. Pelunaan adalah suatu jaminan pelepasan melalui pembayaran suatu harga tertentu. Dan pemberian hidup Kristus merupakan harga pelunasan itu (Markus 10:45). ${ }^{6}$

Dalam Galatia 3:13 menyatakan bahwa Kristus telah menebus kita dari hukum Taurat dengan jalan menjadi kutuk karena kita. Kutuk hokum Taurat adalah hukuman mati. Tanpa pelepasan dari kutuk ini, tidak mungkin ada keselamatan. Tuhan Yesus membayar kita dan harga pembayaran itu adalah diri-Nya sendiri harus dijadikan kutuk. Kutuk itulah yang la tanggung dan kutuk itulah yang la lepaskan, Inilah harga yang telah dibayar Kristus demi penebusan dan kebebasan kita dari belenggu iblis, dosa, dan maut. Dengan demikian, penebusan Kristus adalah kelepasan yang final dan lengkap. Darah Kristus sebagai bayaran pengganti dan sebagai harga pembayaran atas kelepasan manusia berdosa dari kutuk.

Karya penebusan Kristus sangat nyata dalam kehidupan orang percaya, yaitu untuk mendamaikan dan membawa pembenaran, dan memberi kepastian hidup kekal bagi setiap orang yang ada di dalam Kristus. Orang percaya mendapatka jaminan keselamatan dari janji Allah dan

\footnotetext{
${ }^{6}$ Paul Enns, The Moody Handbook Of Theology 1 (Malang: Literatur SAAT, 2016), 263.
} 


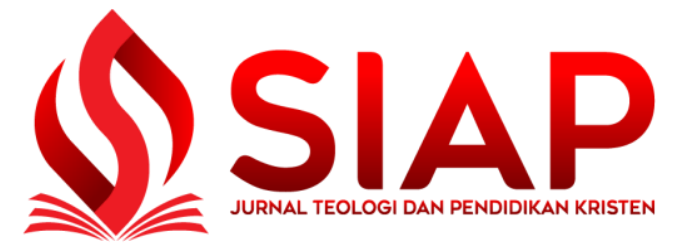

Vol. 10, No. 2 (Desember 2021)

Available Online at :

https://ejournal.sttjki.ac.id/index.php/siap/index

ISSN : 2302-5336X (Cetak) 2808-0459 (Online)

karya penebusan Kristus yang sempurna di atas kayu salib. Bagi setiap orang percaya, keselamatan dijamin oleh pekerjaan Allah Tritungal, khususnya yang berkaitan dengan Anak, yaitu karya penebusan-Nya melalui kematian di kayu salib dan dengan kuasa kebangkitan Kristus mengalahkan maut. Oleh karenanya fakta ini memberikan jaminan bagi kepemilikan hidup kekal. Roma 8: 32-33 menyatakan bahwa "la, yang tidak menyayangkan Anak-Nya sendiri, tetapi yang menyerahkan-Nya bagi kita semua, bagaimanakah mungkin la tidak mengaruniakan segala sesuatu kepada kita bersama-sama dengan Dia?." Karya penebusan Kristus sudah jelas memberikan dampak positif dalam kepastian kepemilikan hidup yang kekal yang dianugerahkan oleh Allah kepada setiap orang yang percaya kepda Yesus Kristus. Hal ini merupakan peneguhan bagi orang-orang yang ada di dalam Kristus. Penebusan Krsitus memberikan jaminan bahwa mereka mempunyai hidup kekal. ${ }^{7}$

\section{Analisa Terhadap Teori-teori yang Menyimpang tentang Penebusan}

Teori tentang penebusan Kristus jelas mengarah kepada Allah untuk menyatakan karya Kristus demi menghindarkan murka Allah dan hukuman Ilahi dari orang berdosa. Karena itu, tidak mungkin ada lebih dari dua teori tentang penebusan Kristus. Namun, ada sejumlah teori yang sepenuhnya subjektif meskipun sesungguhnya bukanlah teori tentang penebusan Kristus. Ada berbagai pandangan, mengenai penebusan. Teori-teori ini perlu diperhatikan dan dianalisa sebab oleh banyak kalangan teori-teori tersebut dianggap sebagai teori penebusan Kristus sehingga menjadi ancaman bagi orang Kristen. Orang Kristen akan terguncang dan akan melemahkan imannya. Beberapa teori yang menyimpang tentang penebusan Kristus adalah:

\footnotetext{
7 Otieli Harefa dkk, "Konsep Penebusan Kristus Dalam Perspektif Teologi Pentakosta”, Jurnal Apostolos, Vol
} 1. No. 2 (November, 2019), 112. 


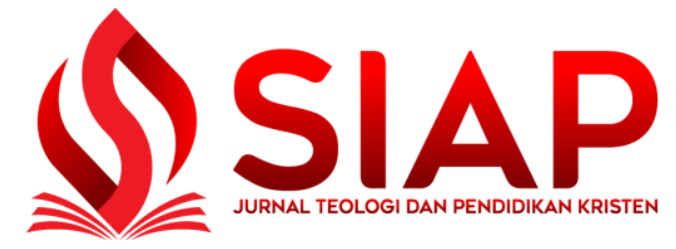

Vol. 10, No. 2 (Desember 2021)

Available Online at :

https://ejournal.sttjki.ac.id/index.php/siap/index

ISSN : 2302-5336X (Cetak) 2808-0459 (Online)

\section{Teori dari gereja abad mula-mula ${ }^{8}$}

Teori pembayaran upah penebusan kepada iblis

Teori ini dari gereja abad mula-mula. Teori ini didasarkan penyataan tunggal bahwa kematian Yesus Kristus merupakan pembayaran upah penebusan kepada iblis sebagai upaya untuk menunda klaim keadilan dari iblis pada manusia. Salah satu tokoh utama teori ini, yaitu Origen, berpendapat bahwa iblis kalah dalam tawar menawar sebab hasilnya menunjukkan si iblis tidak tahan berdiri di hadapan kehadiran Kristus yang kudus dan tidak mampu menguasai Kristus. Teori ini memandang penebusan Kristus sebagai pembayaran yang dilakukan Kristus kepada iblis untuk membebaskan manusia yang diperbudak iblis. Asumsinya adalah kondisi rohani manusia dibelenggu oleh iblis. Oleh karena itu, makna kematian Kristus itu untuk menjamin kemenangan Allah terhadap iblis. Adalah sesat bila menganggap iblis dan bukannya Allah yang menuntut pembayaran untuk dosa, yang juga mengabaikan tuntutan keadilan Allah. Teori ini juga meninggikan iblis lebih dari semestinya dan memperlakukan iblis lebih berkuasa. Iblis tidak memiliki kuasa untuk membebaskan manusia. Tidak benar teori yang menyatakan bahwa penebusan merupakan pembayaran kepada iblis, justru untuk menghancurkan pekerjaan iblis (Kolose 2:15, Ibrani 2:14-16).

Penebusan adalah pembebasan atau membeli dengan membayar, namun tidak mungkin pembayaran dilakukan kepada iblis. Tidak mungkin kepada iblis sebab iblis tidak punya hak sama sekali atas kehidupan manusia. Allah adalah Pemilik kehidupan manusia meskipun manusia telah jatuh dalam dosa. Dengan demikian, pembayaran ini tidak diberikan untuk iblis, tetapi untuk Allah. Hutang yang dihapuskan adalah hutang kepada sifat Allah yang adil. Penebusan artinya membeli kembali (Galatia 3:13) dengan harga bayar (1 Petrus 1:18-20). Allah adalah adil. Agar dosa kita dihapuskan, maka Kristus bersedia menjadi korban pengganti bagi kita. Kristus membayarnya sampai lunas, untuk sekali sampai selama-lamanya (Ibrani 10:10-14). Tidak ada pandangan bahwa orang berdosa berhutang kepada iblis. Hanya Allah yang menuntut

\footnotetext{
${ }^{8}$ Louis Berkhof. Teologi Sistematika: Doktrin Kristus (Jakarta: Lembaga Reformed Injili Indonesia, 1996),
} 189. 


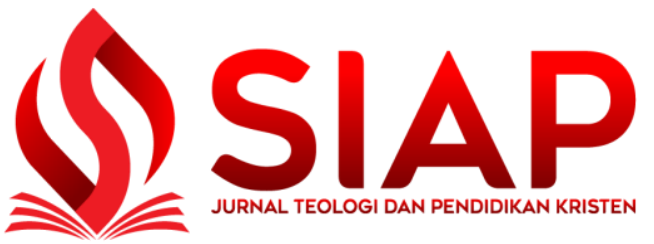

pembayaran untuk dosa, karena itu pembayaran hanya dilakukan Kristus kepada Allah. Manusia yang telah berada di bawah kuasa dosa tidak berdaya membebaskan dirinya. Untuk membebaskan manusia, suatu tebusan dibayar, Kristus membayar tebusan yang dibutuhkan itu dengan kematian-Nya sendiri. Rasul Paulus menggunakan istilah penebusan untuk menggambarkan pelunasan oleh Kristus untuk membebaskan kita dari dosa dan hukumannya sehingga kita mendapat pengampunan dari Allah (Efesus 1:7).

Teori Rekapitulasi

Kristus merekapitulasi semua tingkatan hidup manusia dalam diri-Nya termasuk juga tingkatan yang merupakan milik keadaan kedudukan sebagai orang berdosa. Melalui inkarnasiNya dan kehidupan-Nya sebagai manusia, la membalikkan jalan yang telah dimulai oleh Adam dalam kemanusiannya yang berdosa dan kemudian menjadi baru dalam hidup umat manusia. Teori ini memandang penebusan Kristus sebagai usaha membalikkan jalan hidup manusia dari ketidaktaatan kepada ketaatan. Teori ini percaya bahwa kehidupan Kristus menjadi contoh bagi seluruh tahapan manusia. Dengan demikian, la membalikkan jalan hidup manusia dari ketidaktaatan yang dimulai dari Adam. Bagaimana terjadinya proses membalikkan tidak dijelaskan lebih lanjut dalam teori ini

Kata penebusan digunakan untuk karya Kristus. Kata ini dengan jelas berarti karya yang dengannya Kristus membebaskan kita dari dosa. Tuhan Yesus telah mati karena dosa-dosa manusia. Tuhan Yesus telah menyerahkan nyawa-Nya sebagai Tebusan, yaitu tebusan untuk melepaskan kita dari kematian (Matius 20:28). Karena kematian-Nya, pengampunan diberikan kepada orang-orang berdosa yang bertobat dan percaya (Yesaya 53:10). Seseorang yang sudah menerima karya penebusan Kristus akan taat dalam iman kepada Tuhan Yesus. Penebusan Kristus menjadi dasar kita membangun hidup yang taat kepada Tuhan. Penebusan Kristus harus ditunjukkan dalam kehidupan kita. Ketaatan berarti kita telah sepenuhnya menaruh iman kita pada penebusan dan ketaatan akan menghasilkan perubahan dalam kehidupan. 


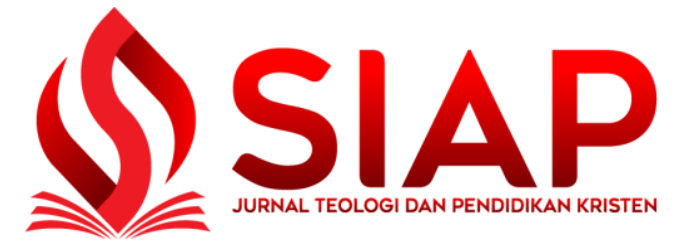

Vol. 10, No. 2 (Desember 2021)

Available Online at :

https://ejournal.sttjki.ac.id/index.php/siap/index

ISSN : 2302-5336X (Cetak) 2808-0459 (Online)

Teori Pemuasan dari Anselmus

Anselmus menekankan penebusan Kristus sebagai kepentingan mutlak dengan cara mendasarkannya pada hal yang paling mendasar, yaitu natur Allah. Dosa terletak pada keadaan makhluk yang menarik diri dari kehormatan Allah yang ditaattinya. Oleh karena dosa manusia, kehormatan Allah diambil daripada-Nya dan itu sebabnya tindakan seperti itu harus dinyatakan kesalahannya. Hal ini dapat dilakukan dengan dua cara: dengan hukuman atau dengan pemuasan. Allah dengan kasih karunia-Nya menyebabkan memilih yang kedua, yaitu menuntut pemuasan dan secara khusus melalui anugerah Putera-Nya yang merupakan satu-satunya jalan sebab yang dituntut sebab yang dituntut adalah pemuasan yang tidak terbatas. Yesus juga menderita dan mati dalam tugas-Nya itu. Anselmus adalah orang pertama yang agak lengkap mengungkapkan sebuah doktrin tentang penebusan Kristus dan teori Anselmus menuju pada arah yang benar dalam banyak segi. Namun, masih perlu dianalisa pendapat Anselmus. Teori Anselmus mendasarkan justru mendasarkan diri pada kehormatan Allah yang seharusnya ditaati. Hal ini mulai dengan prinsip 'hukum pribadi, yang menurut hukum ini satu pihak yang dirugikan dapat menuntut pemuasaan apa pun yang dianggap sesuai. Dan dengan ini membantah perluya penebusan.

Kematian Yesus menyediakan penebusan. Dalam 1 Korintus 6:20 menyatakan bahwa orang percaya "telah dibeli dan harganya telah lunas dibayar". Membeli (agorazo) menggambarkan seorang budak dibeli di pasar budak rakyat. Kristus membeli orang percaya dari pasar budak dosa dan membebaskan mereka (1 Korintus 7:23), maka akibatnya manusia dipulihkan hubungannya dengan Allah. Manusia yang sebelumnya terpisah dari Allah, sekarang diperdamaikan dengan Dia. Penggunaan kata agorazo berkaiatan dengan pemberian suatu harga yang setimpal dengan dosa manusia agar mereka dapat ditebus dan tebusan yang dikerjakan oleh darah Kristus ditujukan bagi Allah.

Teori Anselmus tidak menerima pemikiran bahwa Kristus di dalam penderitaan-Nya menanggung hukuman dosa dan bahwa penderitaan-Nya jelas untuk menggantikan manusia. Kematian Kristus hanya sekedar penghormatan yang secara sukarela diberikan untuk 


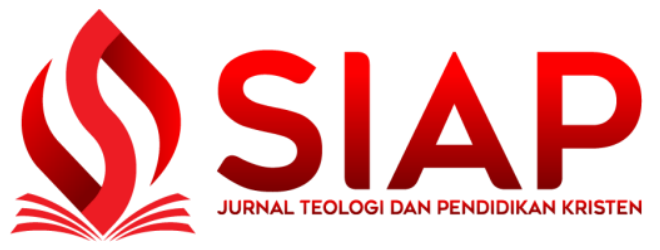

Vol. 10, No. 2 (Desember 2021)

Available Online at :

https://ejournal.sttjki.ac.id/index.php/siap/index

ISSN : 2302-5336X (Cetak) 2808-0459 (Online)

menghornati Bapa. Kematian Kristus memberikan jasa yang lebih dari yang diminta sehingga sanggup membayar hutang jasa orang lain. Kematian Yesus bukan hanya sekedar kehormatan.Yesus Kristus telah mati untuk dosa-dosa manusia. "Kristus telah mati untuk dosadosa kita" (1 Korintus 15:3). Darah Yesus Kristus telah menjadi korban pendamaian karena dosadosa manusia. Karena kematian dan darah Yesus yang tertumpah itu, murka Allah kepada kita telah dihapuskan (Roma 3:25).

Teori ini hanya berpihak pada satu sisi dan karena itu tidak memadai. Teori Anselmus mendasarkan penebusan secara eksklusif pada kematian Yesus yang dianggap sebagai sumbangsih material bagi kehormatan Allah dan menyingkirkan ketaatan Kristus yang aktif sebagai faktor yang memberikan sumbangsih bagi karya penebusan-Nya. Tuhan Yesus telah memberi contoh sempurna dengan merendah diri-Nya dan taat. Di atas kayu salib seluruh penderitaan manusia ditanggung-Nya dan diteguhkan dengan perkataan-Nya "sudah selesai" (Yohanes 19:30).

Penjelasan Anselmus hanya ada sekedar pengalihan eksternal jasa Kristus kepada manusia. Tidak ada petunjuk tentang cara bagaimana karya Kristus dikomunikasikan kepada manusia, tidak ada relasi antara Kristus dan manusia, dan juga tidak dibicarakan tentang iman yang menerima kebenaran yang berasal dari Kristus. Kematian Kristus juga menyediakan pendamaian. Penggunaan kata pendamaian (katallaso) artinya adalah mendamaikan. Secara teologis pendamian dapat diartikan bahwa karena pertobatan dari dosa dan iman kepada Yesus Kristus sebagai Tuhan dan Juru Selamat pribadi, maka perseteruan antara manusia dengan Allah dihancurkan dan terjadi pembaharuan hubungan antara kedua pihak, telah terjadi relasi baru. ${ }^{9}$ Dalam Efesus 2: 15-16 "sebab dengan mati-Nya sebagai manusia la telah membatalkan hukum Taurat dengan segala perintah dan ketentuannya untuk menciptakan keduanya menjadi satu manusia baru di dalam diri-Nya, dan dengan itu mengadakan damai sejahtera, dan untuk memperdamaikan keduanya, di dalam satu tubuh, dengan Allah oleh salib, dengan melenyapkan perseteruan pada salib itu".

\footnotetext{
${ }^{9}$ Chris Marantika. Doktrin Keselamatan dan Kehidupan Rohani (Yogyakarta: Iman Press, 2002), 112.
} 


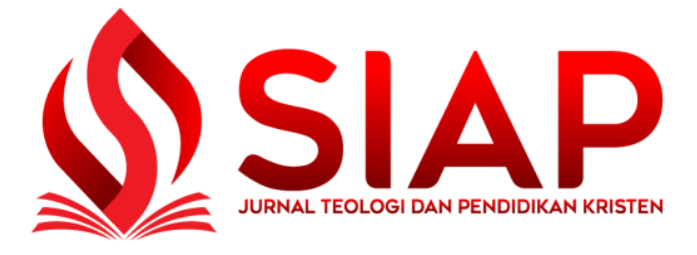

Vol. 10, No. 2 (Desember 2021)

Available Online at :

https://ejournal.sttjki.ac.id/index.php/siap/index

ISSN : 2302-5336X (Cetak) 2808-0459 (Online)

Teori Pengaruh Moral

Pertama kali dikemukakan oleh Albelard yang berusaha menentang Anselmus. Pengertian dasarnya bahwa tidak ada prinsip natur llahi yang perlu pemuasan di pihak orang berdosa dan bahwa kematian Kristus tidak boleh dianggap sebagai penggantian dosa. Kematian Kristus hanyalah merupakan perwujudan kasih Allah, yang ikut menderita bersama makhluk-Nya yang berdosa dan dalam diri-Nya sendiri la mengambil semua kemalangan dan dukacita manusia. Kesengsaraan Kristus memberi kepastian kepada orang berdosa bahwa di pihak Allah sebenarnya tidak ada halangan yang mencegah Dia mengampuni dosa mereka. Satu-satunya syarat adalah bahwa orang berdosa harus datang kepada-Nya dengan hati yang hancur.

Alkitab mengajarkan bahwa orang berdosa tidak memperoleh pengaruh moral dari karya pengorbanan Kristus sampai kebenaran Kristus menjadi miliknya yang diterima dengan iman. Teori ini bertentangan dengan ajaran Alkitab yang jelas menyatakan bahwa karya penebusan Kristus itu perlu bukan terutama untuk mengungkapkan kasih Allah, tetapi untuk memuaskan tuntutan keadilan-Nya. Moral adalah standar perilaku manusia yang baik dan buruk. Standar moral orang percaya tidak sama dengan orang pada umumnya. Moralitas krisitiani Nampak dalam kehidupan orang percaya yang memiliki iman kepada Yesus Kristus, mempunyai norma atau standar yang berpedoman pada kebenaran Firman Tuhan, dan memiliki hati nurani yang murni di hadapan Allah dan sesama

Penderitaan dan kematian Kristus adalah sebagai pengganti hukuman dosa manusia. Allah itu kasih. Dia berinisiatif mengembalikan kita masuk dalam persekutuan dengan Allah. Penyebab kejatuhan adalah dosa, maka Allah harus menyelesaikan masalah dosa manusai. Karena itu, la harus menebus dosa manusia, “...di dalam Dia kita memiliki penebusan kita, yaitu pengampunan dosa (Kolose 1:14). Penebusan artinya membeli kembali (Imaat 4:4-5, Galatia 3:13), Agar dosa kita dihapuskan, Kristus bersedia menjadi korban pengganti bagi kita. Allah adalah adil. Dia tidak mencoba mengganggap dosa kita tidak ada. Yesus Kristus membayarnya sampai lunas, untuk seklai dan selama-lamanya (Ibrani 10:10-14). Kematian Kristus yang tanpa dosa telah menggantikan kita sehingga kita telah dibebaskan dari kutuk dosa, maut dan murka Allah dengan 


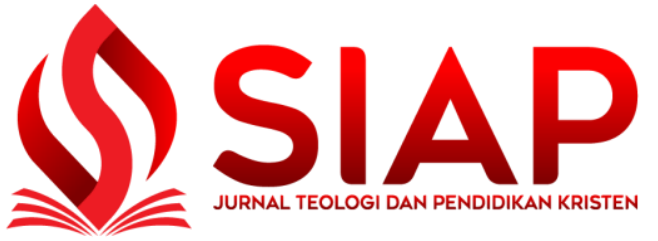

Vol. 10, No. 2 (Desember 2021)

Available Online at :

https://ejournal.sttjki.ac.id/index.php/siap/index

ISSN : 2302-5336X (Cetak) 2808-0459 (Online)

harga bayar yang lunas (1 Korintus 6:20). Kristus yang tanpa dosa menjadi manusia (inkarnasi) agar la dapat mengambil hukuman an amti sebagai pengganti kita. Tujuan kematian Kristus adalah untuk menunjukkan keadilan-Nya (Roma 3:24-26). ${ }^{10}$

Kematian Kristus secara penuh telah memuaskan semua tuntutan kebenaran Allah terhadap orang berdosa. Dengan Kristus taat sampai mati di kayu salib, Allah sudah puas. Manusia tidak perlu berkorban lagi atau berbuat apa pun untuk memuaskan Allah karena tidak akan berhasil untuk memuaskan hati Allah dengan usaha yang dibuat oleh manusia. Tidak peru dan tidak ada perbuatan lain apapun untuk memuaskan hati Allah yang memang sudah puas. Sebelum keamtian Kristus, tidak ada kepastian bagi manusia tentang cara bagaimana ia memuaskan hati Allah. Kini saatnya sudah selesai, Allah sudah puas. ${ }^{11}$ Karena Allah adalah kudus dan benar, maka la tidak dapat mengabaikan dosa. Melalui karya Kristus, Allah sungguh telah dipuaskan secara penuh dan standard kebenaran-Nya telah dipenuhi (Roma 3:25).

Teori ini juga menyingkirkan sifat objektif penebusan Kristus dan dengan demikian berakhir sebagai teori penebusan yang sesungguhnya. Teori ini mencampuradukkan cara Allah menyelamatkan manusia dengan pengalaman manusia yang diselamatkan, dengan menjadikan penebusan Kristus mencakup juga akibatnya dalam kehidupan orang percaya dalam kesatuan dengan Kristus.

Natur penebusan Kristus adalah bersifat objektif, artinya bahwa penebusan Kristus mempunyai kesan pertama pada orang yang olehnya korban ini terjadi. Apabila seseorang melakukan kesalahan dan harus dihukum, hukuman ini dimaksudkan untuk mempengaruhi ornag yang bersalah itu dan bukan pada pihak penuntut hukum. ${ }^{12}$ Penebusan Kristen dimaksudkan untuk meredakan murka Allah dan untuk mendamaikan Dia dengan orang berdosa dan Roh Kudus yang bekerja dalam hatinya. Orang berdosa menyingkirkan keterasingannya yan gjahat dari Allah dan kemudian memasuki buah penebusan ayng sempurna dari Kristus. Oleh sebab penebusan

\footnotetext{
${ }^{10}$ Kalis Stevanus. Jangkauan Penebusan Kristus. "Jurnal Teologi SIAP”, Volume 6, No. 1, Juni 2017, 58.

${ }^{11}$ Marantika, 81-82

12 Louis Berkhof, 162.
} 


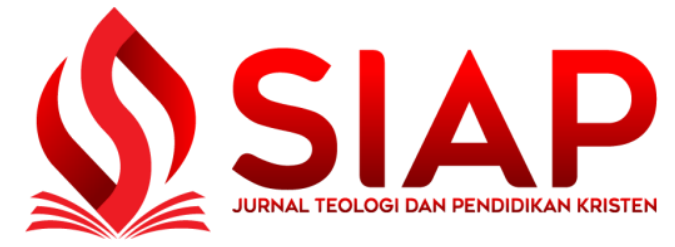

Vol. 10, No. 2 (Desember 2021)

Available Online at :

https://ejournal.sttjki.ac.id/index.php/siap/index

ISSN : 2302-5336X (Cetak) 2808-0459 (Online)

Kristus yang objektif adalah fakta yang sudah digenapi. Kata katalasso dan katalage berarti "mendamaikan" dan "pendamaian" menunjuk pada suatu tindakam yang olehnya permusuhan diubah menjadi persahabatan dan merupakan signifikansi objektif pada mulanya. Orang yang melakukan kesalahan bukan mendamaikan dirinya sendiri, tetapi orang lain yang telah disalahinya. Hal ini secara jelas dinyatakan dalam Matius 5:23-24 "Sebab itu jikalau engkau mempersembahkan persembahanmu di atas mezbah dan engkau teringat akan sesuatu yang ada dalam hati saudaramu terhadap engkau, tinggalkanlah persembahanmu di depan mezbah itu dan pergilah berdamai dahulu dengan saudaramu". Dalam pengertian ini hanya mungkin berarti damaikan saudaramu ini pada dirimu sendiri, yang bersifat objektif. la harus mendamaikan saudaranya dengan dirinya sendiri apapun risikonya yang harus ditanggung.

Menurut 2 Korintus 5:19 kenyataan bahwa Allah mendamaikan dunia dengan diri-Nya sendiri terbukti dalam hal ini bahwa la tidak memperhitungkan kepada mereka sebagai pelanggaran. Hal ini sesungguhnya tidak menunjuk pada kenyataan moral apapun pada manusia, tetapi menunjuk pada kenyataan bahwa tuntutan-tuntutan hukum dipenuhi dan bahwa Allah dipuaskan. Dalam Roma 5:10-11 istilah “pendamaian” hanya dapat dipahami dalam pengertian objektif sebab (1) pendamaian disebabkan oleh kematian Kristus meskipun pendamaian subjektif adalah karya Roh Kudus; (2) pendamaian disebabkan ketika kita masih seteru Allah, yaitu masih sebagai objek murka Allah; (3) dikatakan dalam ayat 11 sebagai sesuatu yag objektif yang kita terima.

\section{Teori Teladan}

Pertama kali teori ini dikemukakan oleh kaum Socinian pada abad ke Sembilan belas yang berlawanan dengan para Reformator bahwa Kristus sebagai pengganti menebus umat manusia. Prinsip dasarnya sesungguhnya tidak ada keadilan dalam diri Allah yang secara mutlak menuntut bahwa dosa harus dihukum. Teori ini juga tidak menetapkan hubungan langsung antara kematian Kristus dan keselamatan orang berdosa. Namun, teori ini menyatakan bahwa kematian Kristus boleh disebut untuk membenarkan orang berdosa berkenaan dengan kenyataan bahwa Kristus 


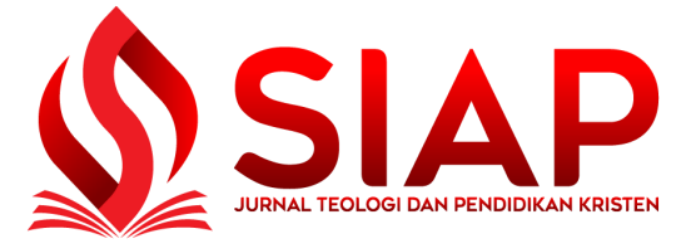

Vol. 10, No. 2 (Desember 2021)

Available Online at :

https://ejournal.sttjki.ac.id/index.php/siap/index

ISSN : 2302-5336X (Cetak) 2808-0459 (Online)

sebagai upah bagi ketaatan-nya samapai mati, memperoleh kuasa untuk memberikan hidup yang kekal bagi orang percaya.

Teori ini tidak menekankan Alkitab.Kristus hanya dianggap manusia biasa yang mempunyai kualitas luar biasa dalam memandang dosa, yang mana sifat dosa adalah kesalahan. Kemanusiaan Yesus Kristus sama petingnya dengan ketuhanan-Nya sebab kalau Yesus bukan sungguh-sungguh manusia, la tidak dapat menjadi korban bagi dosa manusia. Namun, Yesus tidak berdosa. Dalam segala tindakan, Yesus Kristus sungguh seorang manusia sejati, la telah menjadi manusia supaya dapat menebus manusia (Filipi 2:5-8, 2 Korintus 8:9). ${ }^{13}$

Teori ini juga menyebutkan bahwa Kristus juga disebut sebagai teladan dalam Alkitab, namun tidak dikatakan bahwa la adalah teladan yang harus menjadi pola bagi orang berdosa yang tidak percaya dan nanti akan menyelamatkan mereka kalau mereka mengikuti pola Kristus itu. Teladan Kristus adalah teladan yang hanya diikuti oleh murid-murid-Nya. Penderitaan-Nya untuk dosa manusia memotivasi kita untuk menolong orang lain yang mash hidup dalam dosa. Kristus dalam segala hal selalu menjadi teladan bagi manusia (Yohanes 13:15). Teladan Yesus sudah memberi cotoh. la dipenuhi dengan segala keadilan, ketulusan, kesucian, kebajkan dalam melayani orang lain, rendah hati, mengorbankan diri, sungguh-sungguh sebagai teladan manusia (1 Petru2 2:21)

Tuhan Yesus mati bagi setiap orang dari setiap suku dan bangsa di dunia ini. Yesus Kristus telah menyerahkan diri-Nya menjadi Tebusan semua orang (1 Timotius 2:6). Keselamatan tersedia bagi semua orang sehingga ramat Allah boleh diberitakan kepada semua orang. Pengampunan dosa sudah tersedia, yang diperlukan adalah orang yang datang dan menerima pengampunan itu dalam iman kepada Yesus Kristus. Kematian Kristus cukup untuk semua manusia, asalkan mereka bertobat dan percaya kepada-Nya. Alasan pekerjaan pemberitaan Injil adalah supaya kita pergi mencari dan mendapatkan orang-orang dari segala suku bangsa karena Yesus Kristus telah mati juga untuk mereka.

\footnotetext{
${ }^{13}$ J. Wesley Brill. Dasar Yang Teguh (Bandung: Kalam Hidup, 2017), 137.
} 


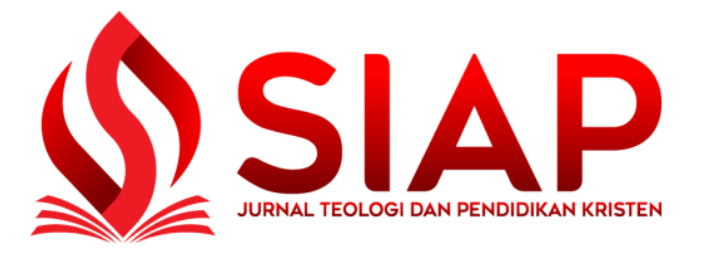

Vol. 10, No. 2 (Desember 2021)

Available Online at :

https://ejournal.sttjki.ac.id/index.php/siap/index

ISSN : 2302-5336X (Cetak) 2808-0459 (Online)

Teori Pertobatan dengan Pengganti

Teori ini disebut juga teori simpati dan identifikasi, dikemukakan oleh Mc. Leo Campbell. Kristus sebagai manusia secara simpati dapat merasakan kesulitan dan pencobaan, dan juga kelemahan yang kita alami. Namun, tidak dijelaskan bagaimana Yesus menjelma menjadi manusia yang memungkinkan Dia memasuki persaan sebagai sahabat. Di dalam Ibrani 2:17: Yesus Kristus sama dengan saudara-Nya dalam banyak hal, secara tubuh, dalam hal pikiran, dalam pengetahuan. la sama seperti manusia biasa, namun tidak sama dalam pengertian moral dengan orang berdosa. Meskipun Yesus Kristus sungguh-sungguh seorang manusia, Tuhan Yesus tidak mewarisi sifat dosa. Manusia mewarisi dosa sebab manusia keturunan Adam. Kelahiran Yesus Kristus adalah karena Roh Kudus, la tidak memilki dosa seperti manusia biasa. 1 Petrus 2:22 menyatakan bahwa Yesus tidak pernah berbuat dosa. Yesus setara dengan Alla dan sama-sama dapat merasakan kelemahan manusia

Teori ini juga menghasilkan prinsip yang salah bahwa dosa tidak harus menjadikan manusia mengalami penghukuman dosa. Kekudusan dan keadilan Allah tidak memerlukan penebusan yang objketif. Satu-satunya pertolongan penebusan adalah karena kemampuan manusia tidak mampu bertobat dengan cara yang benar. Ketika Adam jatuh dalam dosa, maka semua manusia yang lahir dari Adam adalah manusia berdosa, terlhair dalam dosa (Roma 5:12) Dosa dan maut diturunkan oleh satu orang (Roma 5:14). Manusia menerima hukuman mati karena ketidaktaatan satu orang (Kejadian 2:17). Akibat dosa adalah maut, binasa, hidup dalam bayang-bayang maut nerka kekal (Roma 6:23). Manusia tidak mungkin dapat menyelamatkan dirinya dengan memabayar melalui perbuatan baik (Efesus 2:18-19). Keselamatan kekal diperoleh dengan karya Yesus kristus yang mengerjakan penebusan dosa.

Teori ini berdasarkan asumsi bahwa pertobatan yang sempurna dapat menjadi penebusan yang cukup bagi dosa. Hal ini tidak dapat dilakukan manusia untuk melakukan pertobatan yang sempurna, Karya Yesus menyatakan bahwa kematian-Nya sebagai pengganti bagi orang berdosa. Kematian-Nya disebut vicarious yang berarti "seorang sebagai pengganti yang lain. ".Kematian Kristus berkaitan dengan pertobatan dan pengakuan dosa yang memakai penganti. Galatia 3;13 


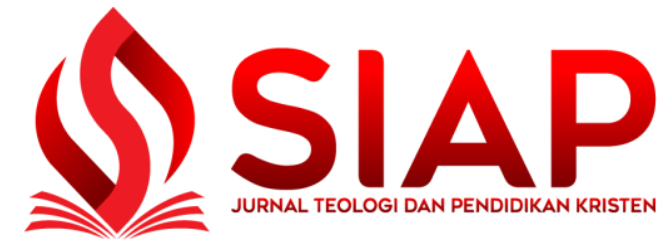

Vol. 10, No. 2 (Desember 2021)

Available Online at :

https://ejournal.sttjki.ac.id/index.php/siap/index

ISSN : 2302-5336X (Cetak) 2808-0459 (Online)

mengajarkan juga bahwa "Kristus telah menebus kita dari kuutk hukum Taurat dengan jalan menjadi kutuk karena kita". Kristus mati sebagai pengganti bagi semua umat manusia. Kristus telah menanggung semua dosa orang percaya. Dia sepenuhnya menebus mereka dan melalaui kematian-Nya, Dia membayar untuk orang percaya. Tebusan Kristus sebagai ganti orang banyak, seperti dinyatakan dalam Matius 20:28 "sama seperti Anak Manusia datang bukan untuk dilayani, melainkan untuk melayani dan untuk memberikan nyawa-Nya menjadi tebusan bagi banyak orang."

\section{Sikap Orang Kristen Menghadapi Ancaman teori penebusan yang menyimpang}

Orang Kristen harus memilki pengenalan yang benar tentang karya penebusan Kristus. Penebusan Krsitus bukan sebagai pembayaran upah penebusan kepada iblis. Kadangkala pengetahuan tentang Firman Tuhan tidak diketahui dengan benar. Alkitab berbicara tentang mengenal Allah. Orang Kristen dihidupkan oleh Allah dalam suatu pegertian yang baru atau dilahirkan kembali. Pengenalan akan Allah meliputi mendengarkan Firman Allah dan menerima seperti yang Roh Kudus menafsirkan dan menerapkan dalam kehidupan kita, dan memperhatikan karakter Allah seperti yang difirmankan, melakukan perintah-perintah Allah, dan bersukacita dalam persekutuan ilahi. ${ }^{14}$ Bagi sebagian orang Kristen, nampaknya hal ini begitu sulit. Namun, pengenalan akan Allah itu penting sehingga orang Kristen akan memasuki pengertian tentang hidup yang kekal. Karya penebusan Kristus memberikan jaminan akan hidup yang kekal. Pengenalan akan Allah juga penting karena melibatkan pengenalan akan diri kita sendiri. Orang Kristen mengenal dirinya sendiri yang adalah manusia berdosa. Keselamatan di dalam Kristus adalah anugerah semata-mata dan dikerjakan melalui penebusan Kristus atas dosa manusia.

Dengan demikian, kita mengenal bahwa diri kita tidak kudus, tidak baik, lemah, sombong, maka pengenalan akanAllah dapat merendahkan hati kita. Pengenalan akan Allah juga memberi pengertian akan dunia ini dan penghakiman yang akan datang, dan pada akhirnya pengenalan akan Allah akan membawa kita pada kekudusan, bukan hanya standar moral seperti yang terdapat dalam teori pengaruh moral.

\footnotetext{
14 James Montgomery Boice, Dasar-Dasar Iman Kristen (Surabaya: Momentum, 2018), 10.
} 
Orang Kristen perlu terus membekali diri dengan pengetahuan yang benar tentang Yesus Kristus, Sang Penebus umat manusia. Orang Kristen mengetahui tentang pribadi Yesus Kristus dan keilahian Yesus Kristus. Buku yang berjudul "Ketika Alkitab Dipertanyakan" memaparkan pertanyaan-pertanyaan yang mucul berkaitan dengan kehidupan dan kematian Yesus Kristus. Penjelasan juga mengarah pada keunggulan Yesus daripada tokoh-tokoh agama yang lain. Tidak ada guru lain yang memberikan keselamatan oleh iman. Tidak ada pemimpin agama yang mau menjadi Penebus dosa manusia yang menunjukkan kasih kepada uamt manusia seperti yang dilakukan Yesus dengan mati menebus dosa-dosa dunia (Yohanes 15: 13). Tuhan Yesus layak disembah sebagai Allah yang Maha Tinggi. ${ }^{15}$ Dengan pengenalan yang benar akan Allah Tritunggal, maka orang Kristen dapat menolak teori penebusan yang menyimpang.

\section{KESIMPULAN}

Kesimpulan dari pembahasan adalah penebusan dosa dikerjakan oleh Yesus Kristus sehingga manusia dapat memperoleh hidup yang kekal. Natur penebusan Kristus bersifat objektif yang memiliki pengertian bahwa penebusan Kristus mempunyai kesan pertama pada orang yang diselamatkan.Terdapat beberapa teori tentang penebusan Kristus yang subjektif.Teori-teori yang menyimpang tentang penebusan Kristus adalah teori-teori dari gereja abad mula-mula, teori pemuasan dari Anselmus, teori pengaruh moral, teori teladan, dan teori pertobatan dan pengganti. Teori-teori ini sangat menyesatkan. Oleh karena itu, pengenalan akan Allah penting bagi orang Kristen agar iman tetap teguh

${ }^{15}$ Norman Geisler dan Ron Brooks, Ketika Alkitab Dipertanyakan (Yogyakarta: Andi, 2008), 162 


\section{BIBLIOGRAFI}

Chris Marantika. Doktrin Keselamatan dan Kehidupan Rohani. Yogyakarta: Iman Press, 2002.

Berkhof, Louis. Teologi Sistematika: Doktrin Kristus. Jakarta: Lembaga Reformed Injili Indonesia, 1996

Boice, James Montgomery, Dasar-Dasar Iman Kristen. Surabaya: Momentum, 2018.

Brill, J. Wesley. Dasar Yang Teguh. Bandung: Kalam Hidup, 2017.

Enns, Paul. Buku Pegangan Teologi. Malang: SAAT, 2012, 400-401 dikutip oleh Kalis Stevanus, Jalan Masuk Kerajaan Surga.Yogyakarta: Andi, 2017

Enns, Paul. The Moody Handbook Of Theology (Malang: Literatur SAAT, 2016).

Erickson, Millard J. Teologi Kristen Volume Dua. Bandung: Gandum Mas, 2003.

Geisler, Norman dan Ron Brooks. Ketika Alkitab Dipertanyakan. Yogyakarta: Andi, 2008.

Harefa, Otieli dkk., Konsep Penebusan Kristus Dalam Perspektif Teologi Pantekosta, Jurnal Apostolos, Vol. 1. No. 2 (November, 2019).

Kusuma, Surja. Kompas Iman. Yogyakarta: Rangkang Education, 2016.

Milne, Bruce. Mengenali Kebenaran. Jakarta: BPK Gunung Mulia, 1996.

Murray, John. Penggenapan dan Penerapan Penebusan. Surabaya: Momentum, 2008.

Stevanus, Kalis. Jangkauan Penebusan Kristus. "Jurnal Teologi SIAP", Volume 6, No. 1, Juni 2017, Surja Kusuma. Kompas Iman .Yogyakarta: Rangkang Education, 2016.

Tarigan, Musa S. "Implikasi Penebusan Kristus Dalam Pendidikan Kristen (The Implication Of Christ's Redemption On Christian Education)", Jurnal Polyglot. Volume 15, No. 2, Juli 2019.

Tong, Stephen. Yesus Kristus Juruselamat Dunia. Surabaya: Momentum, 2005. 